\title{
Effectiveness of Denpasar City Regulation Number: 7 of 2013 on No Smoking Areas
}

\author{
I Ketut Sukadana ${ }^{1}$, Luh Putu Suryani ${ }^{2}$, Ni Made Sukaryati Karma ${ }^{3}$ \\ Faculty of Law, Universitas Warmadewa, Denpasar-Bali, Indonesia \\ \{sukadanaketut1966@gmail.com ${ }^{1}$ \}
}

\begin{abstract}
Smoking is a general phenomenon among teenagers and adults, especially cigarette addicts. Aside from the fact that it impacts one's health negatively, smoking could as well cause harm to others. Therefore, based on the phenomenon, the Denpasar City Government established City Regulation No. 7 of 2013 on Non-smoking Areas. This study aims to to discuss the implementation of Denpasar City Regulation No. 7 of 2013 on Non-smoking Areas in Denpasar City and the factors inhibiting the enforcement of this regulation in these areas. The method used in this study was the empirical legal research with the sociology of law approach. The research data were collected through observation and interviews. The results revealed the need for the government to conduct routine socialization, coaching, and actions that are repressive to violators of the Regional Regulation. This is mainly a judicial action, which is a permanent legal action against violators of the regulation and sanctioned by the provisions. However, the Civil Service Police Unit officers experienced some obstacles in its enforcement and these include a high level of migrant attendance, limited availability of infrastructure, and budget for conducting socialization
\end{abstract}

Keywords: smoking; area; sanctions; obstacles

\section{Introduction}

The lifestyle of smoking has become a habit for many people, especially cigarette addicts, and even smoking is no longer age-conscious, from adolescents to old age and has spread to various groups, from the middle to upper class to the middle to lower economic class. The impact of smoking is one of the dangers that can damage health for both active and passive smokers because in these cigarettes there are substances that are very dangerous to health. The main substances in cigarettes are tar, nicotine, and carbon monoxide (Nururrahmah, 2015). Besides having an impact on one's health, smoking can also harm others. People who are exposed to cigarette smoke directly are known as secondhand smoke. Passive smokers have a greater risk of health problems than active smokers (Bustan, 2000). Passive smokers directly inhale cigarette smoke-exposed by active smokers without an air filter to enter the body so that causes many people to suffer disease and death.

World Health Organization (WHO) records that the death toll is very high, about 11,000 people die each day from tobacco-related diseases. In fact, tobacco each year kills 7 million people worldwide and ironically that number is expected to increase to 10 million in the next 25 years. In fact, tobacco-related diseases are the easiest to prevent. In the provisions of 
Article 28 H paragraph (1) of the 1945 Constitution of the Republic of Indonesia, it is stated: "Everyone has the same rights to obtain a prosperous life both physically and mentally, to obtain a place to live, and to get a good and healthy living environment and entitled to health services". This provision indicates that one form of state policy contained in the constitution is in terms of protecting human rights in the health sector (Yuliarso \& Prajarto, 2005). As a manifestation of these constitutional provisions, the government has formulated Law Number 36 of 2009 concerning health. In the end, the local government followed up with the formation of a Regional Regulation which regulates the existence of a No Smoking Area in several predetermined locations, including the Denpasar City Government which has established the Denpasar City Regional Regulation No. 7 of 2013 concerning No-Smoking Areas, abbreviated as the Denpasar City Regulation on No Smoking Area.

In connection with the above, several previous studies have been carried out, such as research from Rahajeng (2015) concerning the Effect of the Application of No Smoking Areas on the Decrease in the Proportion of Smokers in the Provinces of DKI Jakarta, Yogyakarta, and Bali. It shows that the implementation of Kawasan Dilarang Merokok or No Smoking Area policy affects reducing the proportion of smokers every day. The sectors that play a role are the regional government; consistent law enforcement; routine supervision; stakeholder compliance; positive support from the education sector and the tourism sector; as well as the active role of community organizations. Secondly, Haris, Ikhsan, \& Rogayah (2012) about cigarette smoke as indoor pollution. The results of this study indicate that indoor air pollution is more dangerous than outdoors, cigarette smoke is the main source of indoor air pollution, passive smokers are those who inhale ETS (Environment Tobacco Smoke) which comes from side cigarette smoke and cigarette smoke causes abnormalities in almost all organs of the body. Third, research conducted by (Jin \& Jiang, 2017) concerning E-Cigarettein Ten Southeast Asian Countries. It shows that e-cigarette legal regulations in the region: on the one hand, countries such as Brunei, Cambodia, Thailand, and Singapore have banned the import and sale of e-cigarettes with existing tobacco control laws or special regulations; on the other hand, countries like Myanmar and Vietnam have almost no legal restrictions on e-cigarettes at all. Based on the description above, this current research aims to analyze how the application of the Regional Regulation of the City of Denpasar Number 7 of 2013 concerning NoSmoking Areas in the City of Denpasar and to know the inhibiting factors of Enforcement of Violations of the Denpasar City Regulation Number 7 of 2013 concerning No Smoking Areas in the Denpasar City.

\section{Research Method}

This study was designed in qualitative descriptive approach to empirical legal research. In addition, the problem approach used is the sociological approach, which is seeing reality and collecting data in the field. This research was conducted in the city of Denpasar. The location of Denpasar City as the research location is because the population is relatively large and very heterogeneous, and there are a number of facilities without smoking areas.

There are 2 types of data used, namely primary data (data sourced from field research, namely data obtained directly from the first source, namely both respondents (smokers) and informants from the Denpasar City Health Office and the Denpasar City Government Civil Service Police Unit) and data Secondary includes material from literature, books and other legal materials, including journals that relate to the problems of this research. Data collection techniques used were systematic and directed observation and direct interviews in accordance 
with the legal issues raised in this study. After the data was collected, it was processed quantitatively and qualitatively and was presented in a descriptive analysis in the form of a report.

\section{Results and Discussion}

\subsection{The Scope of No Smoking Area}

As for the scope of the No Smoking Area contained in Regional Regulation No. 7/2013 Chapter III Article (2), namely:

\section{a) Health Care Facilities}

A health service facility is a tool and/or place used to carry out health service efforts, whether promotive, preventive, curative or rehabilitative carried out by the government, local government, and/or the community. Based on Regional Regulation Number 7 of 2013 Article 4 , service facilities health as referred to is a hospital, maternity hospital, polyclinic, health center, medical center, laboratory, posyandu, and private health practice place.

\section{b) Place for Teaching and Learning}

Teaching and learning process place is a building used for learning, teaching, education and/or training activities. Based on Perda Number 7 of 2013 Article 5, the places for the teaching and learning process as referred to are schools, universities, education and training centers, work training centers, tutoring, course venues, and children's playgrounds. And based on Perda No. 7/2013, Article 6, the playgrounds referred to are Play Groups, Child Care, Early Childhood Education (PAUD), and Kindergartens.

\section{c) Worship place}

Places of worship are buildings or closed spaces that have certain characteristics that are permanently used for worship by followers of each religion, excluding family places of worship. Based on Perda No. 7/2013 Article 7, the places of worship referred to are temples, mosques / prayer rooms, churches, monasteries, and temples.

\section{d) Public transportation}

Public transportation is public vehicles which can be in the form of land, water and air vehicles, usually with compensation. Based on Perda Number 7 of 2013 Article 8, public transportation as referred to is public buses, taxis, city transportation, tourist vehicles, school children transportation buses, and employee transport buses.

\section{e) Workplace}

Workplace is any room or field that is closed or open, mobile or permanent where workers work, or where workers enter for the purposes of a business and carry out other work activities. Based on Perda No. 3/2013 Article 9, the workplaces as referred to are: 
Government Offices, both Civilians and Indonesian National Army and Police of the Republic of Indonesia, Industries and Workshops.

\section{f) Public places}

Public places are all closed or open places that can be accessed by the people and/or places that can be used together for community activities managed by the government, the private sector and the community. Based on Perda Number 7 of 2013 Article 10, public places as referred to are: modern markets, traditional markets, tourist attractions, entertainment places, recreation areas, hotels, restaurants, bus stops, public transport terminals, goods transportation terminals, ports and other places set. Other designated places are open spaces that can be jointly used for community activities that have been designated as smoke-free areas under a Mayor Regulation. Based on the provisions of Article 11 of Regional Regulation No. 7/2013, other places referred to are fields, city parks, and pedestrians. The leader or person in charge of the places as determined is obliged to determine and implement KTR. Health service facilities, places for teaching and learning, places for children to play, places of worship and public transportation are the scope of No Smoking Area to be prohibited from providing a special place for smoking and are No Smoking Area or smoke-free to the outer limit. Meanwhile workplaces, public places, and other designated places can provide special places for smoking.

\subsection{Implementation of Regional Regulation Number 7 of 2013 concerning No-Smoking Areas and Obstacles to Enforcement}

The government is an organization that protects the community and as the holder of responsibility for the interests of the people, one of which is order and regulations in order to achieve a calm and smooth life. In addition, it is the government's responsibility to make regulations that will be applied to the community. One of the regulations made by the government is the establishment of a smoking-free zone regulation. The no-smoking area regulation issued by the government is a regulation on No-Smoking Areas where in Denpasar City itself there is a Regional Regulation regarding No-Smoking Areas. Smoking Free Areas are mandatory policies issued by the government, especially local governments as the implementer of Article 115 Paragraph (2) of Law of the Republic of Indonesia Number 36 of 2009 concerning Health, which states that Regional Governments are required to establish Smoking Free Areas in their territories.

Article 115 Paragraph (1) Law of the Republic of Indonesia No. 36 of 2009 concerning Health states that places which are non-smoking areas include health service facilities, places for teaching and learning, places for children to play, places of worship, public transportation, workplaces, and public places and other designated places. To enforce the Regional Regulation, the Civil Service Police Unit has the authority to follow up on it, including the Regional Regulations that have been enacted, namely regarding Smoking Free Areas. Law functions as a protection for human interests (Mertokusumo, 2005). Law enforcement can be carried out normally, peacefully, but it can also occur due to law violations. In this case, the law that has been violated must be enforced. According to Rahardjo (1980), Law enforcement is an effort to bring ideas of legal certainty, social benefits and justice into reality. The process of manifesting these three ideas is the essence of law enforcement. To enforce a legal rule so that it is upright, a legal remedy is required. One of the legal measures that can be taken so that a rule can be enforced is through repressive measures. 
Repressive measures are acts of implementing law or instrument sanctions when there are violations of the provisions of applicable legal norms, usually this is known as law enforcement (Hamzah, 2005). Repressive measures are also intended to crack down on crimes or violations that have violated the prevailing laws and regulations. These repressive measures can be in the form of criminal sanctions or imposition of fines against violated legal norms. In State Administrative Law, the use of administrative sanctions is the government's authority to establish certain administrative law norms, accompanied by giving the authority to enforce these norms through the application of sanctions for those who violate the norms of State Administrative Law (Soejono, 2006).

There are several patterns adopted by the Civil Service Police Unit, namely in the form of calls and sudden inspections (sidak). Appeals are usually associated at the same time with socialization programs to the wider community, such as through mobile fleets equipped with loudspeakers. While unannounced inspections (sidak) are carried out in an integrated manner to follow up on the implementation of Regional Regulation Number 7 of 2013 concerning NoSmoking Areas, with elements of CSI (Civil Servant Investigators) aimed at SCS (State Civil Servants) who violate the regulation, Health Service, Parties. Police, elements of the TNI, namely the Military Police, have a special duty to follow up on members of the police who violate regional regulations, elements of the Attorney General's Office, and certain sub-district heads who are in charge of the locations/places of inspection. The socialization is carried out in order the community will increasingly realize the importance of air in the surrounding environment without being polluted by cigarette smoke. Apart from that, the government also always carries out coaching and acts of a repressive nature.

Judicial action is a permanent legal action against violators of Regional Regulations (Perda) through a judicial process by Civil Servant Investigators and provides sanctions that have been determined in the regional regulation. Based on data obtained from the Civil Service Police Unit of the City of Denpasar, the enforcement of the No Smoking Area Regional Regulations up to 2019 (data until August) is as follows:

Tabel 1. Enforcement of Denpasar City Regional Regulation Number 7 of 2013 concerning No Smoking Areas

\begin{tabular}{lcccc}
\hline & \multicolumn{4}{c}{ Year } \\
\cline { 2 - 5 } Month & $\mathbf{2 0 1 6}$ & $\mathbf{2 0 1 7}$ & $\mathbf{2 0 1 8}$ & $\mathbf{2 0 1 9 *}$ \\
\hline January & 5 & 11 & 6 & 6 \\
February & 9 & 1 & 28 & - \\
March & 7 & 15 & 22 & 7 \\
April & 3 & 20 & 23 & 12 \\
Mey & 7 & 30 & 6 & 10 \\
June & 4 & 14 & 9 & 11 \\
July & 12 & 27 & 16 & 9 \\
August & 16 & 21 & 15 & - \\
September & 8 & 14 & 6 & - \\
October & 11 & 14 & 18 & - \\
November & 6 & - & 4 & - \\
December & 1 & - & - & - \\
\hline Total & $\mathbf{8 9}$ & $\mathbf{1 6 7}$ & $\mathbf{1 5 3}$ & $\mathbf{5 5}$ \\
\hline
\end{tabular}

Source: Civil Service Police Unit Office of Denpasar City

Based on the data table listed above, it can be seen that in 2016 the enforcement of the Regional Regulation without smoking occurred as many as 89 actions. The following year, 2017 saw an increase in the number of violations, namely 167 violations. In 2018 there was a 
decline, namely 153 actions judicially. The number of violations in 2019 (until August there were 55 violations. From this data it can be said that the Regional Regulation Number 7 of 2013 concerning Non-Smoking Areas which was enacted just entered its sixth year, can be said to be quite effective. If viewed from 2016 to 2019 the percentage of violations against Smoking Free Areas has decreased. In the early days it was promulgated up to three years of socialization period, from the results of the control (sidak) there were 89 violations. The following year (2017) there were 167 violations, this means that there was an increase in the violation rate of $46.71 \%$. In 2018 there were 153 violations, which showed a decrease in the percentage of $9.15 \%$. Whereas for 2019 (data up to August), if it is assumed that per month (September-December) there are 10 violations on average so that in 2019 there are 95 violations, then there will be a decrease in violations by $61.05 \%$.

In enforcing the Regional Regulations on No Smoking Areas, sanctions or penalties are imposed on those who violate these regulations. The Regional Regulation on No Smoking Areas itself has been socialized to the community regarding the existence of the Regional Regulation on No Smoking Areas, how the Regional Regulation on No Smoking Areas is implemented, and what types of sanctions are imposed on the community if they violate the Regional Regulations on No Smoking Areas. However, some people do not know the regional regulation concerning No Smoking Areas. The government has carried out socialization related to these rules in various ways, such as conducting seminars, installing billboards, providing circular letters about Smoking Free Areas to government agencies, private companies, schools, traditional villages, Banjars and so ford. Therefore, people who violate the Regional Regulation on No Smoking Areas are subject to sanctions in the form of imprisonment and fines. One of the repressive efforts to crack down on violations against Non-Smoking Areas is to impose sanctions on violators. In the Regional Regulation of the City of Denpasar Number 7 of 2013 concerning No-Smoking Areas, there are 2 alternative sanctions, namely imprisonment and fines.

Based on Regional Regulation Number 7 of 2013 Article 19, what is meant is that any person and / or entity violating the provisions of Article 12 paragraph (1) and paragraph (2) shall be punished with imprisonment of up to 3 (three) months or a maximum fine of Rp. $50,000,000.00$ (fifty million rupiah). Even though the threat of a fine for the violator is worth millions of rupiah, in its implementation, the judge still applies sanctions light reasons namely a fine with a value of tens of thousands of rupiah. Therefore, based on records, violators of the No Smoking Area Regional Regulation choose to pay a fine rather than receive a sanction of imprisonment because it is considered lighter.

Violations of the No Smoking Area Regional Regulations still occur in Denpasar City, because the offenders are new residents who have traveled to Denpasar with various professions. This resident admits that he does not know that there are regulations regarding No Smoking Areas. Residents who use the excuse of this violation are usually met by officers when they are being inspected at the hospital.

No smoking area regulations are needed in office areas to support the health and wellbeing of the people living in the environment. A smoke-free environment can make the environment comfortable for workers. Application of Non-Smoking Areas in the Civil Service Police Unit Office of Denpasar City. In the implementation of regional government, the Regional Head is assisted by regional apparatus, in accordance with article 225 paragraph (1) of the Constitution of the Republic of Indonesia No. 23 of 2014 concerning Regional Government, the Civil Service Police Unit is formed to enforce Regional Regulations / or Regional Head Regulations to provide order. general and public order and provide protection for the community. 
The Civil Service Police Unit received information about the violation of the No Smoking Area by the community and members of the Civil Service Police Unit immediately followed up on the offender. The obstacles experienced by the Civil Service Police Unit officers in enforcing Regional Regulations on No Smoking Areas include the very high presence of immigrants, limited available infrastructure, limited budget for conducting socialization, and sometimes it happens ewuh pakewuh with the person in charge of a place that becomes a Smoking Free Area. Ewuh pakewuh means, officers of the Civil Service Police Unit sometimes feel reluctant to advise the leadership of an educational institution because they should already understand the rules, but in reality they still don't understand so that there are still violations in their institutions (interview with I Made Poniawan on 27 September 2019).

\section{Conclusion}

The application of Denpasar City Regional Regulation Number 7 of 2013 concerning NoSmoking Areas in general can be carried out effectively, although there are still several violations. This is due to routine outreach and coaching as well as repressive actions against the offender. Justisial action is a permanent legal action against violators of a Regional Regulation (Perda) through a judicial process and is subject to sanctions in accordance with the provisions of the Perda. The obstacles experienced by the Civil Service Police Unit officers in enforcing Regional Regulations on No-Smoking Areas include, among others, the very high presence of immigrants, limited available infrastructure, limited budget for conducting socialization, and sometimes ewuh pakewuh occurs with the person in charge of a place into a No Smoking Area. Ewuh pakewuh this means, officers of the Civil Service Police Unit sometimes feel a little reluctant to advise the leadership of an educational institution because they should already understand the rules, but in reality they still don't have legal awareness.

\section{References}

[1] Bustan, M. . (2000). Epidemiologi Penyakit Tidak Menular. Jakarta: PT Rineka Cipta.

[2] Hamzah, A. (2005). Hukum Acara Pidana Indonesia. Jakarta: Sinar Grafika.

[3] Haris, A., Ikhsan, M., \& Rogayah, R. (2012). Asap Rokok Sebagai Bahan Pencemar dalam Ruangan. Cermin Dunia Kedokteran, 39(1), 17-20.

[4] Jin, P., \& Jiang, Y. J. (2017). E-Cigarettein Ten Southeast Asian Countries: A Comparison of National Regulation. Global Health Journal, 1(3), 1-10.

[5] Mertokusumo, S. (2005). Mengenal Hukum Suatu Pengantar. Yogyakarta: Liberty.

[6] Nururrahmah. (2015). Pengaruh Rokok Terhadap Kesehatan dan Pembentukan Karakter Manusia. Prosiding Seminar Nasional, 01(1), 78.

[7] Rahajeng, E. (2015). Pengaruh Penerapan Kawasan Tanpa Rokok Terhadap Penurunan Proporsi Perokok di Provinsi DKI Jakarta, Daerah Istimewa Yogyakarta dan Bali. Jurnal Ekologi Kesehatan, 238-249. https://doi.org/10.1016/j.jbankfin.2017.09.006

[8] Rahardjo, S. (1980). Hukum dan Masyarakat. Bandung: Angkasa.

[9] Soejono, T. (2006). Penegakan Hukum di Indonesia. Jakarta: Prestasi Pustaka.

[10] Yuliarso, K. K., \& Prajarto, N. (2005). Hak Asasi Manusia (HAM) di Indonesia: Menuju Democratic Governances. Jurnal Ilmu Sosial Dan Ilmu Politik, 8(3), 291-308. 
